\title{
Carbon fluxes in the Canadian Arctic: patterns and drivers of bacterial abundance, production and respiration on the Beaufort Sea margin
}

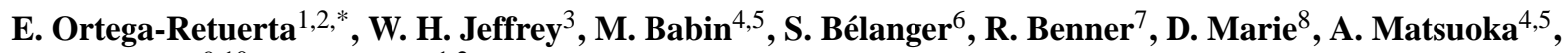 \\ P. Raimbault ${ }^{9,10}$, and F. Joux ${ }^{1,2}$ \\ ${ }^{1}$ UPMC Univ Paris 06, UMR7621, Laboratoire d'Océanographie Microbienne, Observatoire Océanologique, 66650 \\ Banyuls/mer, France \\ ${ }^{2}$ CNRS, UMR7621, Laboratoire d'Océanographie Microbienne, Observatoire Océanologique, 66650 Banyuls/mer, France \\ ${ }^{3}$ Center for Environmental Diagnostics and Bioremediation, University of West Florida, Pensacola, FL, USA \\ ${ }^{4}$ Laboratoire d'Océanographie de Villefranche, UMR7093, Université Pierre et Marie Curie (Paris 6)/Centre National de la \\ Recherche Scientifique (CNRS), B.P. 08, Port de la Darse, Villefranche-sur-Mer Cedex, 06230, France \\ ${ }^{5}$ Takuvik Joint International Laboratory, Université Laval (Canada) - CNRS (France), Département de Biologie and \\ Québec-Océan, Université Laval, Pavillon Alexandre-Vachon 1045, avenue de la Médecine, Local 2078, G1V 0A6, Canada \\ ${ }^{6}$ Departement de Biologie, Chimie et Géographie, Université du Québec à Rimouski, Rimouski, Quebec, G5L 3A1, Canada \\ ${ }^{7}$ Department of Biological Sciences, University of South Carolina, Columbia, SC 29208, USA \\ ${ }^{8}$ CNRS, UMR7144 and UPMC (Paris 6), Station Biologique de Roscoff, Place G. Teissier, 29680 Roscoff, France \\ ${ }^{9}$ Aix-Marseille Univ., Mediterranean Institute of Oceanography (MIO), 13288, Marseille, Cedex 09, France \\ ${ }^{10}$ Université du Sud Toulon-Var, MIO, 83957, La Garde cedex, France \\ * present address: Institut de Ciències del Mar, CSIC 08003, Barcelona, Spain
}

Correspondence to: E. Ortega-Retuerta (ortegaretuerta@icm.csic.es) and F. Joux (joux@ obs-banyuls.fr)

Received: 19 April 2012 - Published in Biogeosciences Discuss.: 25 May 2012

Revised: 19 August 2012 - Accepted: 28 August 2012 - Published: 27 September 2012

\begin{abstract}
During August 2009, measurements of bacterial abundance and nucleic acid content were made along with production and respiration in coastal waters of the Beaufort Sea (Arctic Ocean), an area influenced by the Mackenzie River inflow. The main purpose was to evaluate bacterial organic carbon processing with respect to local sources, mainly primary production and river inputs. Bacterial production and abundance generally decreased from river to offshore waters and from surface to deep waters. In contrast, the percentage of high nucleic acid bacteria was higher in deep waters rather than in surface or river waters. Statistical analyses indicated that bacterial production was primarily controlled by temperature and the availability of labile organic matter, as indicated by total dissolved amino acid concentrations. Direct comparisons of bacterial carbon demand and primary production indicated net heterotrophy was common in shelf waters. Net autotrophy was observed at stations in
\end{abstract}

the Mackenzie River plume, suggesting that the carbon fixed in plume waters helped fuel net heterotrophy in the Beaufort Sea margin.

\section{Introduction}

Heterotrophic prokaryotes (Bacteria and Archaea, hereafter bacteria) are at the centre of the balance between mineralised and exported carbon in pelagic ecosystems (Azam et al., 1983); either catabolising it into $\mathrm{CO}_{2}$ to obtain energy (bacterial respiration, BR) or using it for anabolism; that is, building new bacterial biomass (bacterial production, BP). The prevalence of these two processes, expressed as growth efficiency, largely determines the fate of organic carbon channelled through the microbial food web. Estimating rates of biogeochemical cycles, among which are the carbon fluxes 
mediated by bacteria, is a major challenge, and of particular importance in the Arctic Ocean in view of assessing its sensitivity to climate change effects (Bates et al., 2011). In high latitude ecosystems such as the Arctic, bacteria are exposed to persistently low temperatures and extreme seasonal changes in environmental parameters such as irradiance or nutrient availability (Hollibaugh et al., 2007). Despite their low temperatures, polar ecosystems support a highly productive ice-free season (Garneau et al., 2008), and bacterial activity has been found to be as high as in lower latitudes (Wheeler et al., 1996). However, previous studies suggest low efficiency of the microbial loop in polar ecosystems, shown by low bacterial production to primary production ratios and low bacterial growth rates (Kirchman et al., 2009b). Although temperature can partly account for this limitation, the low availability of substrate (Kirchman et al., 2009b) or the combination of these two (Pomeroy and Wiebe, 2001) appear to be the key factors driving bacterioplankton activity and, hence, fluxes of carbon through them.

Major changes in the Arctic Ocean are occurring due to increasing temperatures, the retreat and thinning of multiyear ice (Perovich, 2011) and the increase of river runoff and associated terrestrial organic matter due to permafrost melting (Peterson et al., 2002; Lalande et al., 2009). Specifically in the Beaufort Sea, ice melting and the influence of the Mackenzie River discharge enhance the formation of a strong upper pycnocline that prevents the exchange of nutrients with deeper water masses (McLaughlin et al., 2011). If this pycnocline becomes stronger due to an increase in ice melt and river inputs, a decrease in primary production due to nutrient limitation is predicted (Comeau et al., 2011). On the other hand, the increase in annual river discharge and permafrost melting will provide alternative sources of organic substrates for bacteria. Although some studies indicate that much of this organic matter is refractory to bacterial utilisation (Meon and Amon, 2004), river inputs can partly sustain bacterial metabolism in the area (Garneau et al., 2006; Vallières et al., 2008). Changes on these processes will ultimately affect the magnitude and quality of substrates available to bacteria and will influence patterns of net autotrophy vs. heterotrophy in the Beaufort Sea.

Owing to the expected changes in the Arctic ecosystem due to global warming, a reliable estimation of all the processes governing carbon fluxes in the area becomes a priority. In this sense, the magnitude and variability of organic carbon channelled through bacterioplankton via production or respiration is one of the central questions. In this paper, we investigated bacterial abundance and activity proxies, presenting simultaneous measurements of bacterial abundance, high nucleic acid and low nucleic acid bacteria discrimination, BP and BR in the coastal Beaufort Sea during summer. These data allow us to compare bacterial carbon utilisation with carbon standing stocks and primary production in the area, and to explore the environmental drivers of bacterioplankton activity combining regression analyses of in situ data and experimental approaches.

\section{Material and methods}

\subsection{Study sites and sampling}

The sampling stations were distributed along 7 transects (named 100 to 700 from East to West). The station number belonging to each transect was increasing from North to South, hence, from offshore waters to coastal waters in the Mackenzie River plume. For instance, the transect 600 started offshore with station number $610\left(70.795^{\circ} \mathrm{N}\right.$, $220.397^{\circ} \mathrm{W}$ ) and ended with station number 697 in the Mackenzie River mouth (Fig. 1). Sampling was carried out from 30 July to 27 August 2009 onboard the research icebreaker CCGS Amundsen in the framework of the MALINA project. Water samples were collected using a SBE Carousel with 20 12-1 PVC bottles (Ocean Test Equipment) and equipped with a SBE911-plus CTD profiler. The sampling strategy was continuously adapted to account for ice distribution and the position of the river plume. CTD vertical profiles were generally recorded from surface down to $200 \mathrm{~m}$, and samples were collected at 6 depths between surface and right below the deep chlorophyll maximum. A zodiac was used to sample shallow waters $(<20 \mathrm{~m})$ along two transects located in the two main effluents of the Mackenzie River. Seawater was collected manually at the surface $(0.5$ to $1 \mathrm{~m}$ ) using 51 clean carboys.

\subsection{Biological analyses}

\subsubsection{Bacterial abundance and biomass}

Bacterial cells (BA) were counted onboard by flow cytometry using a FACS ARIA (Becton Dickinson, San Jose, CA) equipped with $488 \mathrm{~nm}$ and $633 \mathrm{~nm}$ lasers and the standard filters setup. Samples were fixed with glutaraldehyde $0.25 \%$ (final concentration) and then stored at $-80^{\circ} \mathrm{C}$. SYBR Green-I was added at a final dilution of 1/10000 and samples were incubated in the dark for $15 \mathrm{~min}$ before analysis of about $100 \mu \mathrm{l}$ in the presence of $0.95 \mu \mathrm{m}$ fluorescent beads (Polysciences). Bacteria were detected on a plot of green fluorescence $(515-545 \mathrm{~nm})$ versus right angle light scatter (SSC), using the green fluorescence as threshold parameter. High Nucleic Acid (HNA) and low Nucleic Acid (LNA) bacteria were discriminated according to their green fluorescence and counted separately. The discrimination between HNA and LNA cells has been attributed to different phylogenetic compositions or used as a proxy for active and non-active components of the bacterial community (Gasol et al., 1999). To convert BA to bacterial biomass, we first determined the mean bacterial biovolume on 75 samples stained with $2.5 \mu \mathrm{g} \mathrm{I}^{-1}$ of $4^{\prime}-6^{\prime}$-diamidino-2-phenylindole (DAPI) and using epifluorescence microscoscope (AX70, Olympus 


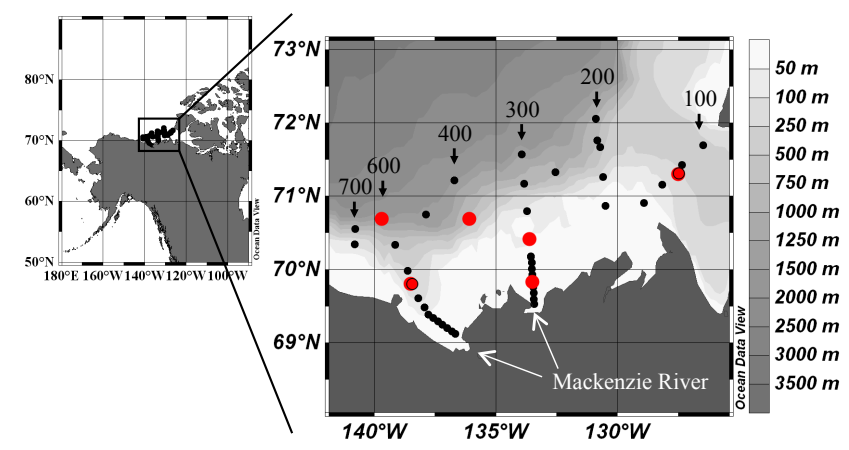

Fig. 1. Study area. Transect numbers from the sampling grid are marked by top labels. Stations where respiration experiments were performed are marked in red.

Provis) with semi-automated image analysis (Cottrell and

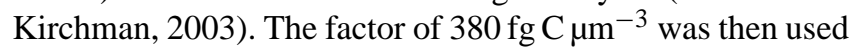
to convert biovolume in biomass (Lee and Fuhrman, 1987). The mean estimated biovolume was $0.04 \pm 0.009 \mu \mathrm{m}^{3}$, which lead to a cell to carbon conversion factor of $15.2 \mathrm{fg} \mathrm{C} \mathrm{cell}^{-1}$ that was used to calculate the average bacterial biomass.

\subsubsection{Bacterial production}

BP was measured by ${ }^{3} \mathrm{H}$-leucine incorporation (Kirchman, 1993) as modified by Smith and Azam (1992). Samples $(1.5 \mathrm{ml}$ in triplicate) were added to sterile microcentrifuge tubes (Eppendorf, $2 \mathrm{ml}$ ), containing $10-20 \mathrm{nM}\left[4,5-{ }^{3} \mathrm{H}\right]-$ leucine (specific activity $139 \mathrm{Ci} \mathrm{mmol}^{-1}$, Amersham). The final concentration of ${ }^{3} \mathrm{H}$-leucine was determined to be saturating in preliminary experiments (data not shown). Samples were incubated for $2 \mathrm{~h}$ in the dark at in situ temperatures. One killed control was prepared for each assay by addition of trichloroacetic acid (TCA) at $5 \%$ final concentration, $15 \mathrm{~min}$ before the addition of leucine. Incorporations were terminated by adding TCA ( $5 \%$ final concentration). Samples were stored for at least $1 \mathrm{~h}$ at $4{ }^{\circ} \mathrm{C}$, processed using the centrifuge method of Smith and Azam (1992), and radioactivity determined by liquid scintillation counting. Leucine incorporation rates were converted into carbon production using the conversion factor of $1.5 \mathrm{~kg} \mathrm{C}$ produced per mole of leucine incorporated (Kirchman et al., 2009a) and considering no isotope dilution.

\subsubsection{Community and bacterial respiration}

Total community (TCR) and free-living bacterial respiration (BR) were determined on whole water and samples filtered by gravity on 1- $\mu$ m filter capsule (Polycap TC, Whatman), respectively. Samples were dispensed into ten to twelve $60 \mathrm{ml}$ calibrated biological oxygen demand (BOD) bottles. The BOD bottles were allowed to overflow $\sim 3$ times the volume of the bottle, ensuring that no bubbles remained in the bottles and capped free of headspace with ground glass stop- pers. The BOD bottles were incubated in the dark at in situ temperature in a water bath to prevent gas exchange. At time zero, 5-6 BOD bottles were fixed with Winkler reagents for the determination of dissolved oxygen (DO) concentration. Community and bacterial respiration rates were determined by following the decrease in DO in 5-6 BOD bottles after 72 to $120 \mathrm{~h}$ taking intermediate time points at some cases. In all these the $\mathrm{O}_{2}$ consumption vs. time relationship was found to be linear. $\mathrm{O}_{2}$ concentrations were measured via an automated titration procedure using a Mettler DL22 equipped with a potentiometric electrode (Carrignan et al., 1998). Only significant $(p<0.05)$ decreases in $\mathrm{O}_{2}$ are reported, which represented 13 out of 19 respiration experiments (detection limit of the technique $<1 \mu \mathrm{M}$ ). TCR and BR were expressed in $\mathrm{mg} \mathrm{C} \mathrm{m} \mathrm{C}^{-3} \mathrm{~d}^{-1}$ using a respiratory quotient of 1 (del Giorgio and Cole, 1998).

Bacterial carbon demand (BCD, $\mathrm{mg} \mathrm{C} \mathrm{m}^{-3} \mathrm{~d}^{-1}$ ) was calculated as the sum of BP and TCR. Bacterial growth efficiency (BGE, \%) was calculated from $\mathrm{BGE}=\mathrm{BP} /(\mathrm{BP}+\mathrm{TCR}) . \mathrm{BGE}$ and $\mathrm{BCD}$ were calculated using total community respiration measurements assuming that a substantial portion of bacterial respiration is due to particle-attached bacteria (i.e., bacteria retained by the $1 \mu \mathrm{m}$ filter).

\subsubsection{Primary production}

At each productivity station, rates of carbon fixation (primary production, $\mathrm{PP}$ ) were determined using a ${ }^{13} \mathrm{C}$ isotopic technique (Raimbault and Garcia, 2008). For this purpose, three 580-ml samples were collected at minimum sun elevation or before sunrise at 6-7 depths between the surface and the depth where irradiance was $0.3 \%$ of the surface value and poured into acid-cleaned polycarbonate flasks. Bottles were rinsed after use with $10 \% \mathrm{HCl}$, then with distilled water from a Milli-Q ion exchange unit. A $2.4 \%$ solution of $\mathrm{NaH}^{13} \mathrm{CO}_{3}$ (99.9 atom $\%{ }^{13} \mathrm{C}$, EURISOTOP) tracer was added to all flasks $(0.5 \mathrm{ml}$ into $580 \mathrm{ml}$ of water) inducing a ${ }^{13} \mathrm{C}$ enrichment of around $10 \%$. Incubations were carried out immediately following tracer addition in an on-deck incubator. This consisted of 6-7 opaque boxes, each with associated neutral and blue screens, allowing around $50 \%, 25 \%, 15 \%$, $8 \%, 4 \%, 1 \%$ and $0.3 \%$ light penetration. At 5 stations, incubations were also performed in situ on a drifting rig with incubation bottled positioned at the same depth where samples for on-deck incubations were collected. After $24 \mathrm{~h}$, samples were filtered through precombusted $\left(450^{\circ} \mathrm{C}\right)$ Whatman $\mathrm{GF} / \mathrm{F}$ filters $(25$-mm diameter, nominal porosity $\approx 0.7 \mu \mathrm{m})$ using a low vacuum pressure $(<100 \mathrm{~mm} \mathrm{Hg})$. After filtration, filters were placed into $2-\mathrm{ml}$ glass tubes, dried for $24 \mathrm{~h}$ in a $60^{\circ} \mathrm{C}$ oven and stored dry until laboratory analysis. These filters were used to determine the final ${ }^{13} \mathrm{C}$ enrichment ratio in the particulate organic matter on an Integra-CN mass spectrometer calibrated using glycine references for every batch of $10-15$ samples. 


\subsubsection{Chlorophyll $a$, chemical and optical analyses}

Concentrations of chlorophyll $a(\mathrm{Chl} a)$ were determined using the fluorometric method described by Parsons et al. (1984). Samples were filtered onto Whatman GF/F filters and extracted with $90 \%$ acetone for $18 \mathrm{~h}$ at $4{ }^{\circ} \mathrm{C}$ in the dark. The fluorescence was measured before and after acidification with a Turner Designs Model 10-AU fluorometer.

Dissolved organic carbon (DOC) was measured using the high-temperature combustion method in a Shimadzu TOCV (Davis and Benner, 2005). Filtered water samples were stored frozen until analysis in the laboratory. Total dissolved amino acids (TDAA) were measured as o-phthaldialdehyde (OPA) derivatives using an Agilent 1100 high performance liquid chromatography system with a fluorescence detector (Davis and Benner, 2005).

The detailed methodology to determine light absorption coefficient of CDOM $\left(a_{\mathrm{CDOM}}(\lambda), \mathrm{m}^{-1}\right)$ is described in Matsuoka et al. (2012). Briefly, 250-ml aliquots from the seawater samples collected with the Rosette sampler or from the Zodiac were poured in clean glass-bottles and kept in the cold and the dark until analysis onboard the ship. Aliquots were then filtered with $0.2 \mu \mathrm{m}$ GHP filters (Acrodisc Inc.) to determine light absorption by CDOM using a liquid-waveguide spectrophotometer (UltraPath, World Precision Instruments Inc.). A 2-m optical pathlength was used for almost all samples, except for coastal waters at the Mackenzie River mouth where a $0.1 \mathrm{~m}$ optical pathlength was used. The absorption coefficients of CDOM, $a_{\mathrm{CDOM}}(\lambda)$ (in $\mathrm{m}^{-1}$ ) was obtained from 250 to $750 \mathrm{~nm}$ with $1-\mathrm{nm}$ increments.

\subsection{Influence of Mackenzie River water on bacterial production}

To assess the impact of dissolved organic and inorganic nutrients from the Mackenzie River on marine BP, we performed and enrichment experiment using waters from the offshore station $345,71.33^{\circ} \mathrm{N}, 132.55^{\circ} \mathrm{W}$, bottom depth $580 \mathrm{~m}$ ), both from surface and the depth of the chlorophyll maximum $(60 \mathrm{~m})$. We added water filtered by gravity through a $0.2-\mu \mathrm{m}$ filter capsule (Polycap AS, Whatman) from the Mackenzie River (station $694,62.20^{\circ} \mathrm{N}, 137.19^{\circ} \mathrm{W}$ ) on whole seawater (10\% inoculum, $250 \mathrm{ml}$ total volume) in triplicate and incubated in the dark at $4{ }^{\circ} \mathrm{C}$ for $48 \mathrm{~h}$, measuring BP at the end of the incubations. Controls were done with adding $10 \%$ of $0.2-\mu \mathrm{m}$ filtered water from the same location.

\subsection{Statistical analyses}

We tested for any significant differences on bacterial metrics among the different water masses using non-parametric Kolmogorov-Smirnoff tests. To explore the main drivers of bacterial activity in the area, linear regressions were performed on $\log _{10}$-transformed data. When more than one sig- nificant regressor was found, partial coefficients were calculated after multiple regression analyses.

\section{Results}

\subsection{Environmental data}

The Beaufort Sea margin during MALINA cruise was characterised by well-developed temperature and salinity stratification, with mixed layers ranging from 4 to $20 \mathrm{~m}$. Predominant Easterly winds caused the Mackenzie River plume to flow to the West, and an upwelling region could be observed in coastal waters of Eastern transect 100, near cape Bathurst. Cloudy days and ice coverage in offshore stations prevailed during the cruise. Chl $a$ concentration in the area ranged from 0.04 to $17 \mathrm{mg} \mathrm{m}^{-3}$. A deep $\mathrm{Chl} a$ maximum was always observed, between $29 \mathrm{~m}$ near the Mackenzie River plume and $70 \mathrm{~m}$ at offshore stations. By contrast, primary production was generally highest in the upper mixed layer where it ranged from $0.230 \mathrm{mg} \mathrm{m}^{-3} \mathrm{~d}^{-1}$ at station 780 to $544 \mathrm{mg} \mathrm{m}^{-3} \mathrm{~d}^{-1}$ at river station 398. Below the upper layer it ranged from 0.03 to $9.47 \mathrm{mg} \mathrm{m}^{-3} \mathrm{~d}^{-1}$.

For a better description of bacterial metrics, we considered four subgroups of samples according to different water masses: (1) those from the Mackenzie River plume collected along the river transects (mean temperature $7.4^{\circ} \mathrm{C}$, salinity ranging from 0 to $27 \%$, mean $16.8 \%$ o), (2) those from the upper mixed layer above the pycnocline (generally above $30 \mathrm{~m}$, mean temperature $1.5^{\circ} \mathrm{C}$, mean salinity $27.8 \%$ ), (3) those from below the upper mixed layer down to $100 \mathrm{~m}$ corresponding to Pacific Summer Water (mean temperature $-1.1{ }^{\circ} \mathrm{C}$, mean salinity $31.6 \%$ ) and (4) those from below $100 \mathrm{~m}$ corresponding to Pacific Winter Water (mean temperature $-1.4^{\circ} \mathrm{C}$, mean salinity $32.9 \%$, see Matsuoka et al., 2012).

\subsection{Distribution of bacterial parameters}

In Table 1, we provide the average and range of bacterial metrics measured during the study. BP varied over 3 orders of magnitude, from 8.8 to $7078 \mu \mathrm{g} \mathrm{Cm}^{-3} \mathrm{~d}^{-1}$, (mean value $897.1 \pm 1364 \mu \mathrm{g} \mathrm{Cm}^{-3} \mathrm{~d}^{-1}$ ), while $\mathrm{BA}$ only varied within less than 2 orders of magnitude (from 0.83 to $16.2 \times$ $10^{5} \mathrm{cell} \mathrm{ml}^{-1}$ ). The percentage of high nucleic acid cells was also highly variable, ranging from 28 to $81 \%$ (Table 1). Growth rates $\left(\mathrm{d}^{-1}\right)$, that is, bacterial production $\left(\mu \mathrm{g} \mathrm{C} \mathrm{m}{ }^{-3} \mathrm{~d}^{-1}\right.$ ) divided by bacterial biomass $\left(\mu \mathrm{g} \mathrm{C}^{-3}\right)$, averaged $0.08 \mathrm{~d}^{-1}$ and ranged from 0.01 to $0.54 \mathrm{~d}^{-1}$.

BP was positively related to total bacterial abundance $\left(R^{2}=0.69, p<0.001, n=145\right)$. The regression equation was $\left[\log _{10}(\mathrm{BA})\right]=-9.9+2.21\left[\log _{10}(\mathrm{BP})\right]$. However, no significant relationship was found between BP and the percentage of HNA cells $\left(R^{2}=0.02, p>0.05\right)$. Similarly, the slopes of the BP-BA and BP-HNA regressions were not significantly different (data not shown). 
Table 1. Averages ( \pm standard deviation) and ranges of bacterial production (BP), abundance (BA), percentage of high nucleic acid bacteria (HNA), growth rates and bacterial production to primary production ratios (BP : PP) considering all data, Mackenzie River waters, marine waters within the upper mixed layer, marine waters from below the upper mixed layer to $100 \mathrm{~m}$, and deep waters below $100 \mathrm{~m}$.

\begin{tabular}{|c|c|c|c|c|c|c|c|c|c|c|}
\hline & \multicolumn{2}{|c|}{ 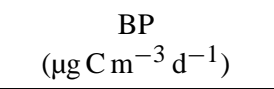 } & \multicolumn{2}{|c|}{$\begin{array}{c}\text { BA } \\
\left(\times 10^{5} \text { cell ml }^{-1}\right)\end{array}$} & \multicolumn{2}{|c|}{$\begin{array}{l}\text { HNA } \\
(\%)\end{array}$} & \multicolumn{2}{|c|}{$\begin{array}{l}\text { Growth Rate } \\
\qquad\left(\mathrm{d}^{-1}\right)\end{array}$} & \multicolumn{2}{|l|}{$\mathrm{BP}: \mathrm{PP}$} \\
\hline & $\begin{array}{r}\text { Mean } \\
(\min -\max )\end{array}$ & $n$ & $\begin{array}{r}\text { Mean } \\
(\min -\max )\end{array}$ & $n$ & $\begin{array}{r}\text { Mean } \\
(\min -\max )\end{array}$ & $n$ & $\begin{array}{r}\text { Mean } \\
(\min -\max )\end{array}$ & $n$ & $\begin{array}{r}\text { Mean } \\
(\min -\max )\end{array}$ & $n$ \\
\hline Total & $\begin{array}{r}897.1 \pm 1364 \\
(8.8-7078)\end{array}$ & 171 & $\begin{array}{l}4.29 \pm 3.05 \\
(0.83-16.2)\end{array}$ & 139 & $\begin{array}{l}56 \pm 14 \\
(28-81)\end{array}$ & 138 & $\begin{array}{l}0.08 \pm 0.10 \\
(0.01-0.54)\end{array}$ & 145 & $\begin{array}{l}0.81 \pm 1.25 \\
(0.01-9.21)\end{array}$ & 82 \\
\hline River transects & $\begin{array}{r}4058 \pm 1440 \\
(374.9-7078)\end{array}$ & 16 & $\begin{array}{l}13.1 \pm 2.02 \\
(10.8-16.2)\end{array}$ & 8 & $\begin{array}{r}42 \pm 5 \\
(35-49)\end{array}$ & 8 & $\begin{array}{l}0.17 \pm 0.06 \\
(0.02-0.23)\end{array}$ & 8 & $\begin{array}{l}0.14 \pm 0.18 \\
(0.01-0.43)\end{array}$ & 5 \\
\hline Mixed Layer & $\begin{array}{r}783.1 \pm 916.5 \\
(54.2-3817)\end{array}$ & 55 & $\begin{array}{r}4.66 \pm 2.94 \\
(1.73-14.00)\end{array}$ & 44 & $\begin{array}{r}46 \pm 9 \\
(30-67)\end{array}$ & 44 & $\begin{array}{r}0.10 \pm 0.09 \\
(0.01-0.54)\end{array}$ & 46 & $\begin{array}{l}0.89 \pm 1.83 \\
(0.05-9.21)\end{array}$ & 35 \\
\hline $\begin{array}{l}\text { Below mixed } \\
\text { layer }\end{array}$ & $\begin{array}{r}528.3 \pm 840.3 \\
(9.3-3593)\end{array}$ & 85 & $\begin{array}{l}3.59 \pm 0.85 \\
(1.31-10.9)\end{array}$ & 74 & $\begin{array}{l}61 \pm 12 \\
(28-81)\end{array}$ & 73 & $\begin{array}{l}0.07 \pm 0.10 \\
(0.01-0.49)\end{array}$ & 74 & $\begin{array}{l}0.80 \pm 0.96 \\
(0.05-4.76)\end{array}$ & 41 \\
\hline Below $100 \mathrm{~m}$ & $\begin{array}{l}32.9 \pm 38.6 \\
(8.8-157.0)\end{array}$ & 15 & $\begin{array}{l}1.70 \pm 0.85 \\
(0.83-3.66)\end{array}$ & 13 & $\begin{array}{r}71 \pm 8 \\
(56-78)\end{array}$ & 13 & $\begin{array}{l}0.01 \pm 0.01 \\
(0.01-0.04)\end{array}$ & 12 & $\begin{array}{l}- \\
-\end{array}$ & 0 \\
\hline
\end{tabular}

Integrated BP over the photic layer averaged $25.4 \pm$ $19.1 \mathrm{mg} \mathrm{C} \mathrm{m}^{-2} \mathrm{~d}^{-1}$ and was significantly higher $(p<0.01)$ at coastal (e.g., less than $200 \mathrm{~m}$ bottom depth) than at offshore stations. Integrated BA averaged $21 \times 10^{9}$ cells m$^{-2}$. In contrast to BP, there was no significant difference between coastal and offshore stations.

$\mathrm{BP}$ and BA in volumetric values showed similar geographic variability patterns, going from highest values in the vicinity of the river plume, to lowest values in the deepest offshore stations (Fig. 2a and c). This was confirmed by negative correlations between BP and station bottom depth $\left(R^{2}=0.57, p<0.001, n=173\right)$, and BA and bottom depth $\left(R^{2}=0.32, p<0.001, n=145\right)$. Conversely, \% HNA did not show any significant trend with station bottom depth (Fig. 2e).

Looking at vertical profiles, BP exhibited highest values in surface samples in 22 out of 27 stations. BA also had generally highest values at the surface in 18 out of 24 measured stations. This was confirmed by significantly higher values of $\mathrm{BP}$ and $\mathrm{BA}$ in river stations and the upper mixed layer than in deeper waters $(p<0.001)$. Nevertheless, there were exceptional stations with high BA at the bottom (e.g., coastal stations 380 and 390, in the slope between the river and the sea (Fig. 2d). In contrast to BP and total BA, \% HNA was significantly lower in river stations and the upper mixed layer than in deeper waters (Table $1, p<0.001$ ). Maxima of $\%$ HNA cells (69 and $81 \%$ ) were observed in samples at the bottom of stations 360 and 380, corresponding to the continental slope (Fig. 2f). Although this matched relatively high BA, it did not coincide with increases in BP (Fig. 2b).

Figure 3 shows some examples of vertical profiles in contrasting coastal and offshore locations. Interestingly, surface maxima of BP and BA were not coincident with vertical profiles of Chl $a$, whose maxima were situated between 29 (coastal station \# 690) and $70 \mathrm{~m}$ (offshore stations \# 540 and
\# 760). Aside from those surface maxima, we observed a second peak in BP and, particularly, in BA, coinciding with Chl $a$ maxima, in 7 out of 24 stations (Fig. 3a, $\mathrm{d}$ and f).

$\mathrm{BP}$ to PP ratios, indicative of the efficiency of carbon uptake by bacteria, averaged $0.81 \pm 1.25$ and ranged from 0.01 to 9.21 , with the BP: PP ratios significantly lower $(p<0.001)$ in the Mackenzie River stations (mean 0.14) than in marine stations (mean 0.89 in the polar mixed layer and 0.80 in deeper waters, Table 1$)$.

Total community respiration (TCR) ranged from 5.5 to $45.5 \mathrm{mg} \mathrm{C} \mathrm{m}^{-3} \mathrm{~d}^{-1}$, while free-living bacterial respiration (BR) ranged from 4.1 to $33.8 \mathrm{mg} \mathrm{C} \mathrm{m}^{-3} \mathrm{~d}^{-1}$ (Table 2). The mean contribution of free-living bacteria (fraction $<1 \mu \mathrm{m}$ ) to TCR was $70.6 \%$ with the exception of one datapoint, where BR exceeded TCR. Differences in TCR and BR patterns were not explained by either changes in BP or BA, nor geographical of physico-chemical variability. Using the measured TCR as an estimator of BR, the average bacterial growth efficiency (BGE) was 7.7 $\pm 7.5 \%$ (Table 2). BGE was significantly $(p<0.05)$ higher in coastal stations (mean 13.7 $\%$ ) than in offshore stations (mean 1.6\%). Bacterial carbon demand (BCD), as the sum of BP and BR (using TCR as a proxy of BR), averaged $21.49 \pm 14.9 \mathrm{mg} \mathrm{C} \mathrm{m}^{-3}$, considering those stations where respiration was directly measured. We compared these values with PP at the same stations by calculating BCD : PP ratios. Values of BCD : PP lower than 1 indicates autotrophy, that is, more carbon fixed by photosynthesis than demanded by bacteria, and higher than 1 indicates heterotrophy or higher carbon demand than fixed carbon. These values ranged from 10.8 to 39 , meaning that BCD exceeded PP rates measured in situ in all stations with coincident measurements. To extrapolate this over the whole sampling grid, we used the average BGE $(7.7 \%)$ to calculate $\mathrm{BCD}$ in all stations where BP was measured and compared $\mathrm{BCD}$ to $\mathrm{PP}$ using integrated values over the euphotic layer. 
Table 2. Total community respiration (TCR, $\mathrm{mg} \mathrm{C} \mathrm{m}^{-3} \mathrm{~d}^{-1}$ ), free-living bacterial respiration (BR $\mathrm{mg} \mathrm{C}^{-3} \mathrm{~d}^{-1}$ ), percentage of respiration associated to free-living bacteria (\%), bacterial growth efficiency (BGE, \%), bacterial carbon demand (BCD, $\left.\mathrm{mg} \mathrm{C} \mathrm{m}^{-3} \mathrm{~d}^{-1}\right)$ and $\mathrm{BCD}$ to primary production (PP, $\left.\mathrm{mg} \mathrm{C} \mathrm{m}^{-3} \mathrm{~d}^{-1}\right)$ ratio.

\begin{tabular}{|c|c|c|c|c|c|c|c|c|c|c|}
\hline Lat & Lon & St. Id & Depth & TCR & $\mathrm{BR}$ & $\begin{array}{r}\% \text { free } \\
\text { BR }\end{array}$ & $\begin{array}{r}\text { BGE (\%) } \\
\text { Using TCR }\end{array}$ & $\begin{array}{l}\text { BGE (\%) } \\
\text { Using BR }\end{array}$ & $\mathrm{BCD}$ & BCD : PP \\
\hline $69.51^{\circ} \mathrm{N}$ & $133.41^{\circ} \mathrm{W}$ & 394 & surface & 45.5 & na & na & 8.7 & na & 49.9 & 4.5 \\
\hline $70.40^{\circ} \mathrm{N}$ & $133.61^{\circ} \mathrm{W}$ & 380 & ' & 11.6 & 33.8 & 292 & 12.9 & 4.8 & 13.3 & 7.5 \\
\hline $69.80^{\circ} \mathrm{N}$ & $138.44^{\circ} \mathrm{W}$ & 670 & “ & 5.5 & 4.1 & 74 & 19.4 & 24.5 & 6.8 & 3.3 \\
\hline $70.70^{\circ} \mathrm{N}$ & $139.63^{\circ} \mathrm{W}$ & 620 & ، & 18.5 & 11.4 & 62 & 2.8 & 4.5 & 19.0 & 5.7 \\
\hline $70.68^{\circ} \mathrm{N}$ & $136.05^{\circ} \mathrm{W}$ & 460 & “ & 18.6 & 15.1 & 81 & 1.7 & 2.0 & 18.9 & 20.3 \\
\hline \multirow{3}{*}{$71.31^{\circ} \mathrm{N}$} & \multirow{3}{*}{$127.47^{\circ} \mathrm{W}$} & \multirow{3}{*}{135} & Chl Max & 21.0 & 13.3 & 63 & 0.4 & 0.6 & 21.1 & 22.0 \\
\hline & & & surface & na & 10.2 & na & na & 3.4 & na & na \\
\hline & & & Chl Max & na & 53.0 & na & na & 0.2 & na & na \\
\hline
\end{tabular}

na: not available
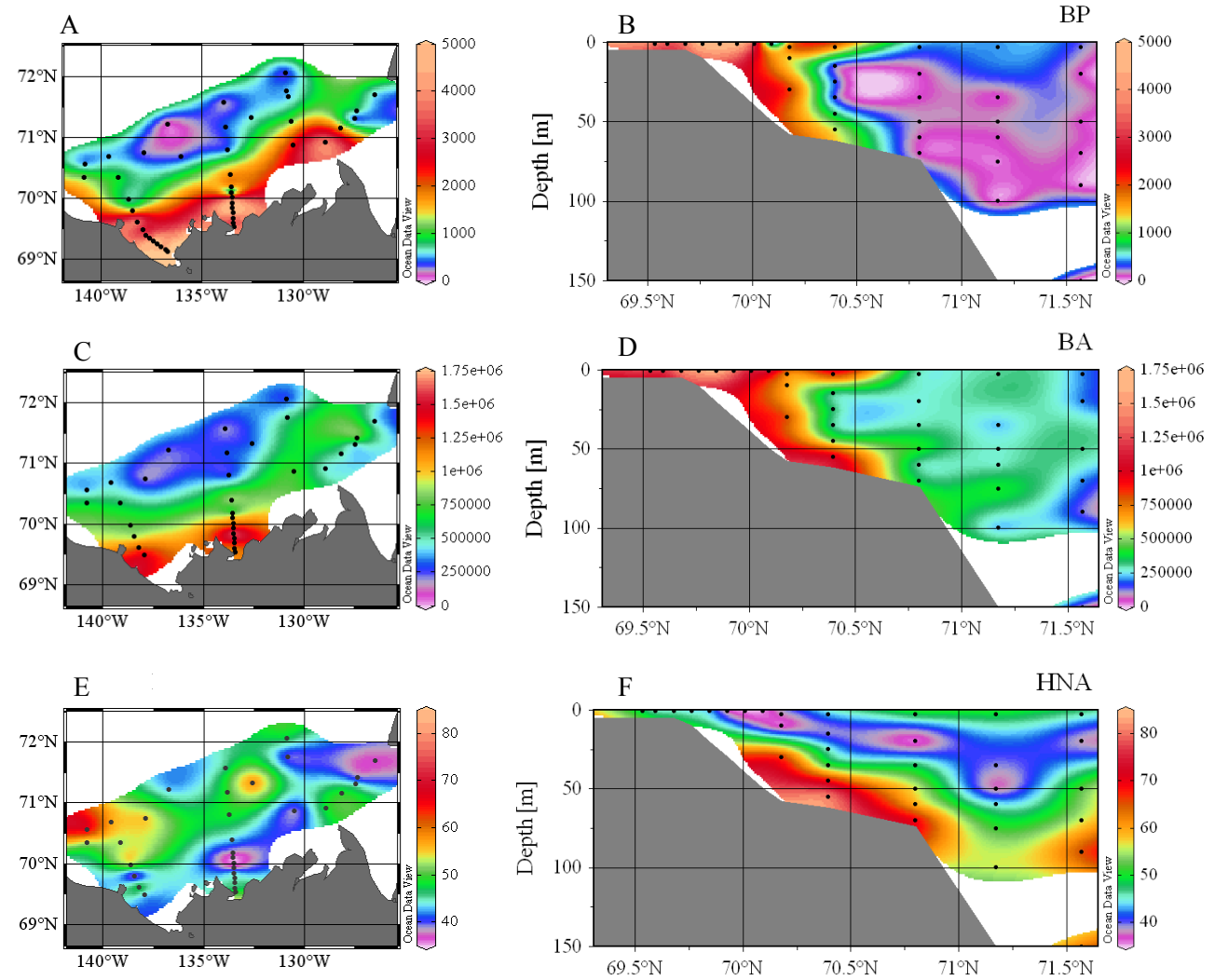

Fig. 2. Surface values (left panels) and vertical profiles belonging to transect 300 from river to sea (right panels) of bacterial production (BP, $\left.\mu \mathrm{g} \mathrm{C} \mathrm{m}^{-3} \mathrm{~d}^{-1}, \mathbf{A}, \mathbf{B}\right)$, bacterial abundance $\left(\mathrm{BA}\right.$, cell $\left.\mathrm{ml}^{-1}, \mathbf{C}, \mathbf{D}\right)$, and percentage of high nucleic acid cells $(\% \mathrm{HNA}, \mathbf{E}, \mathbf{F})$.

We observed that $\mathrm{BCD}$ was on average 10 times higher than $\mathrm{PP}$, but ranged from 0.08 to 50 . $\mathrm{BCD}: \mathrm{PP}$ was higher than 1 in all stations except the most riverine ones, and there was a tendency to lower $\mathrm{BCD}: \mathrm{PP}$ ratios in offshore locations, that increased towards the coast (Fig. 4). This trend was inverted in the Mackenzie River mouth (temperature higher than $8^{\circ} \mathrm{C}$, salinity below $18 \%$ ), where values below 1 were observed (Fig. 4).

\subsection{Driving factors of bacterial production in the area}

To explore the potential driving factors of BP in the area, we tested linear regressions using a broad set of physical (temperature, salinity), chemical (dissolved organic matter, inorganic nutrients) and biological (Chl $a$ concentration, $\mathrm{PP})$ properties as independent variables and $\mathrm{BP}$ as dependent variable. We observed significant and positive relationships 

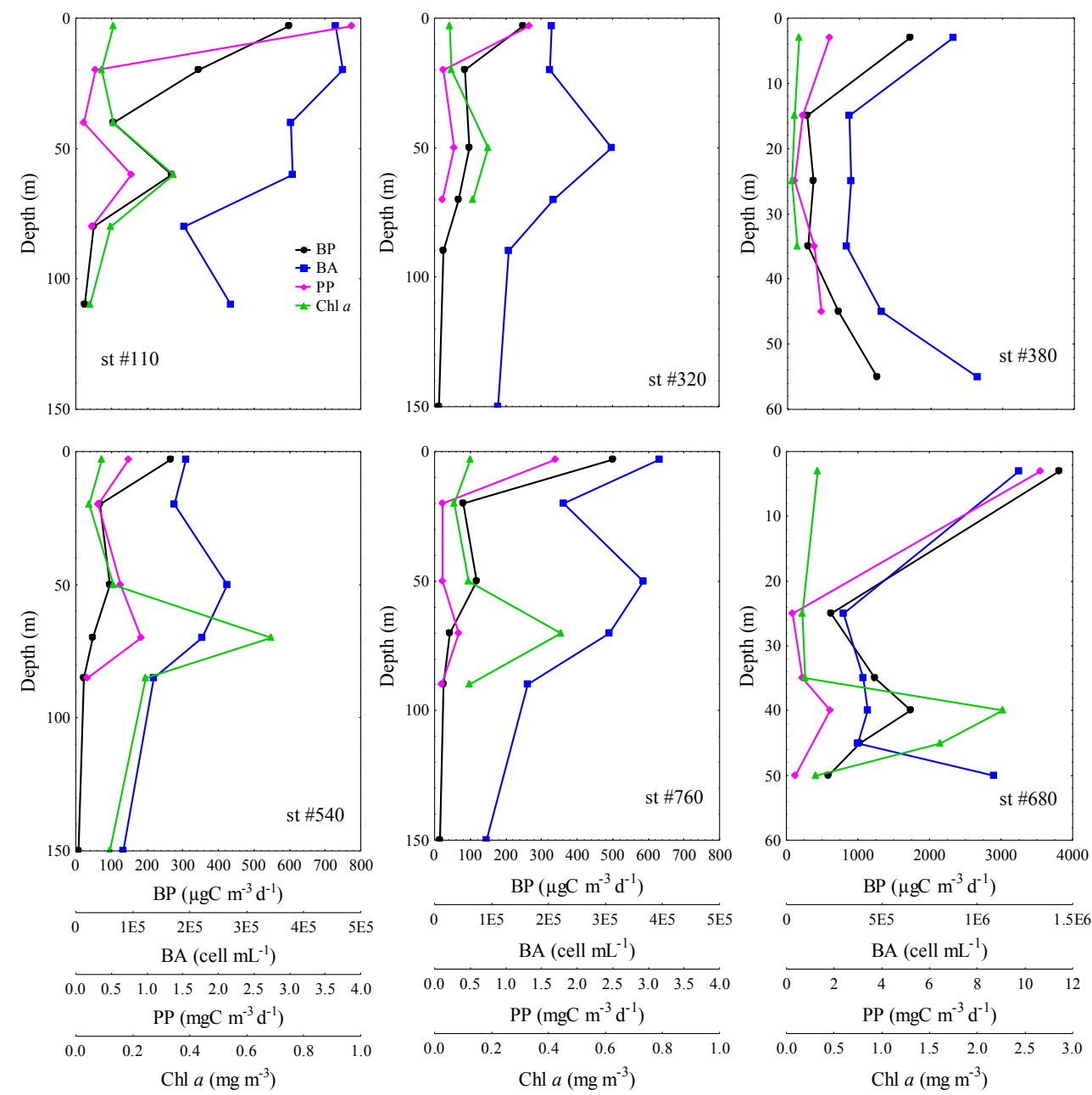

Fig. 3. Vertical profiles of bacterial production (BP, $\left.\mu \mathrm{g} \mathrm{C} \mathrm{m}^{-3} \mathrm{~d}^{-1}\right)$, bacterial abundance $\left(\mathrm{BA}, \times 10^{5}\right.$ cell $\left.\mathrm{ml}^{-1}\right)$, primary production $(\mathrm{PP}$, $\left.\mathrm{mg} \mathrm{C} \mathrm{m}{ }^{-3} \mathrm{~d}^{-1}\right)$ and $\mathrm{Chl} a$ concentration $\left(\mathrm{mg} \mathrm{m}^{-3}\right)$ in selected offshore (st \#110, 320, 540 and 760) and coastal (st \#380 and 680) stations. Note the different scales in the axes

between BP and temperature and between BP and different organic matter surrogates: dissolved organic carbon (DOC), total dissolved amino acids (TDAA), coloured dissolved organic matter (CDOM, $a_{440} \mathrm{~m}^{-1}$ ), Chl $a$ concentration and PP (Table 3). These relationships varied when separating the analyses among the different water masses. The relationship with temperature was characterised by similar slopes in Mackenzie River and upper mixed layer samples and a significantly steeper slope in samples below the upper mixed layer (Table 3, Fig. 5a). On the other hand, the DOC-BP relationship depicted a saturation curve; that is, showed a higher slope when considering waters below the upper layer than in the mixed layer and Mackenzie River waters (Fig. 5b). This pattern, although less marked, was observed with the TDAA$\mathrm{BP}$ and $a_{440}$-BP relationships (Table 3, Fig. $5 \mathrm{c}$ and d). Finally the BP-Chl $a$ and BP-PP plots showed higher slopes in the upper layer than below it (Fig. 5e and f) and illustrated that highest $\mathrm{BP}$ values did not correspond to highest $\mathrm{Chl} a$ concentrations (Fig. 5e).

Because we found more than one factor to explain BP variability, we calculated partial coefficients using forward stepwise multiple regression analyses using a combination of temperature, DOC, TDAA, CDOM, Chl $a$ and PP as independent variables. The results pointed to temperature (partial coef. $=0.55, p<0.01$ ) and TDAA (partial coef. $=0.46$, $p<0.05$ ) as significant factors driving BP in marine waters. The same observations were made using bacterial growth rate rather than $\mathrm{BP}$ (data not shown).

\subsection{Effect of riverine water addition on bacterial production}

The addition of $0.2-\mu \mathrm{m}$ filtered water from the Mackenzie River led to contrasting effects on BP. In the enrichment experiment performed with surface waters, BP was 
Table 3. Results of regression analyses between temperature, DOC, TDAA, CDOM, chlorophyll $a$ concentration and primary production and bacterial production, all in $\log _{10}$. For the analysis, either all data or separated into the different water masses are considered.

\begin{tabular}{|c|c|c|c|c|c|}
\hline \multirow{2}{*}{\multicolumn{2}{|c|}{$\begin{array}{l}\text { Dependent Variable } \\
\text { Independent Variable }\end{array}$}} & \multicolumn{4}{|c|}{ Bacterial Production } \\
\hline & & Total & River & Upper ML & Below ML \\
\hline \multirow[t]{4}{*}{ Temperature } & slope & $1.29 \pm 0.11$ & $1.25 \pm 0.47$ & $1.43 \pm 0.20$ & $3.99 \pm 0.67$ \\
\hline & $r^{2}$ & 0.47 & 0.34 & 0.50 & 0.28 \\
\hline & $p$ & $* * *$ & * & $* * *$ & $* * *$ \\
\hline & $n$ & 167 & 16 & 55 & 88 \\
\hline \multirow[t]{4}{*}{ DOC } & slope & $2.47 \pm 0.28$ & - & $3.35 \pm 0.65$ & $15.29 \pm 3.30$ \\
\hline & $r^{2}$ & 0.55 & 0.04 & 0.53 & 0.46 \\
\hline & $p$ & $* * *$ & ns & $* * *$ & $* * *$ \\
\hline & $n$ & 66 & 13 & 26 & 27 \\
\hline \multirow[t]{4}{*}{ TDAA } & slope & $3.96 \pm 0.30$ & - & $3.58 \pm 0.50$ & $5.02 \pm 0.86$ \\
\hline & $r^{2}$ & 0.74 & 0 & 0.68 & 0.47 \\
\hline & $p$ & $* * *$ & $\mathrm{~ns}$ & $* * *$ & $* * *$ \\
\hline & $n$ & 66 & 13 & 26 & 24 \\
\hline \multirow[t]{4}{*}{$\operatorname{CDOM}\left(a_{440}\right)$} & slope & $1.05 \pm 0.14$ & $0.50 \pm 0.19$ & $1.05 \pm 0.20$ & $2.55 \pm 0.92$ \\
\hline & $r^{2}$ & 0.26 & 0.36 & 0.34 & 0.09 \\
\hline & $p$ & $* * *$ & * & $* * *$ & ** \\
\hline & $n$ & 154 & 15 & 53 & 86 \\
\hline \multirow[t]{4}{*}{ Chl $a$} & slope & $0.65 \pm 0.12$ & - & $0.98 \pm 0.14$ & $0.56 \pm 0.15$ \\
\hline & $r^{2}$ & 0.27 & 0.24 & 0.62 & 0.29 \\
\hline & $p$ & $* * *$ & ns & $* * *$ & $* * *$ \\
\hline & $n$ & 77 & 8 & 33 & 36 \\
\hline \multirow[t]{4}{*}{$\mathrm{PP}$} & slope & $0.54 \pm 0.08$ & - & $0.68 \pm 0.13$ & - \\
\hline & $r^{2}$ & 0.38 & 0.47 & 0.44 & 0.43 \\
\hline & $p$ & $* * *$ & ns & $* * *$ & $\mathrm{~ns}$ \\
\hline & $n$ & 81 & 5 & 35 & 41 \\
\hline
\end{tabular}

ns: not significant $* * *: p<0.0001,{ }^{* *}: p<0.01, *: p<0.05$

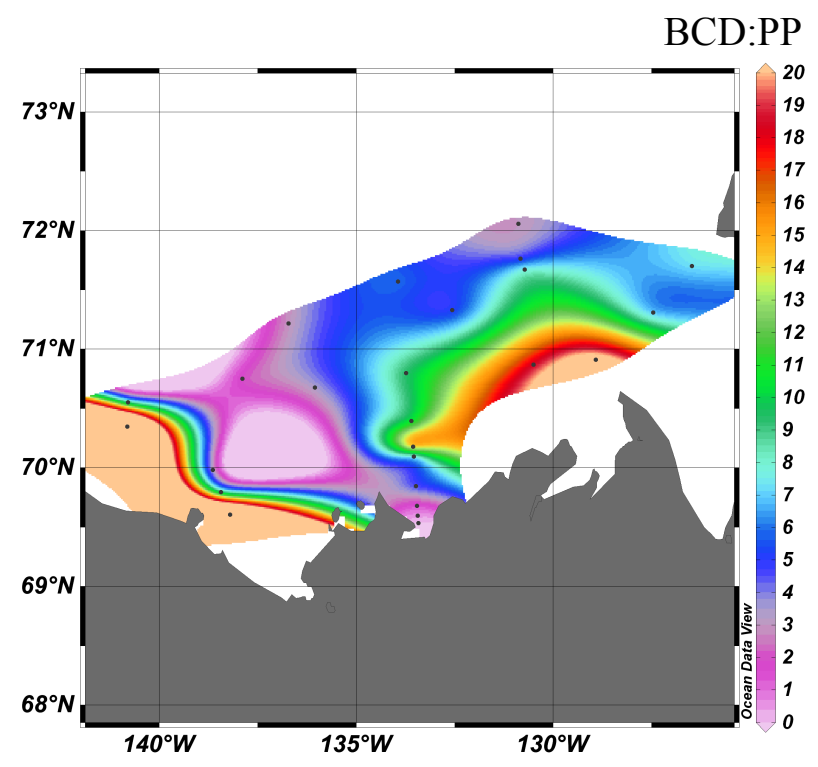

Fig. 4. Spatial pattern of bacterial carbon demand (BCD) to primary production $(\mathrm{PP})$ ratios using values integrated over the euphotic layer. Values above 1 represent net heterotrophic stations. significantly ( $p<0.05$ ) higher when enriched with Mackenzie River water, with a BP enhancement of $43 \%$ (Fig. 6). By contrast, no significant effect of Mackenzie River water was observed in the experiment performed with Chl $a$ max waters.

\section{Discussion}

\subsection{Patterns of bacterial abundances and production}

Bacterial production and abundance in the Beaufort Sea margin during the MALINA cruise were within the broad range of those previously reported in the same and other areas of the Western Arctic Ocean (Table 4). The observed vertical distributions of BP and BA reveal a pattern with maxima near the surface, which coincided with maxima of PP, but not with vertical maxima in Chl- $a$ concentration. These surface maxima, added to the increasing trend in BA and BP from the sea towards the river, suggest the influence of the Mackenzie River controlling PP and bacterial activity in the system.

Growth rates were consistent with previous works in the Western Arctic (Table 4), but at the lower end of those reported in other ocean areas, which has classically been 

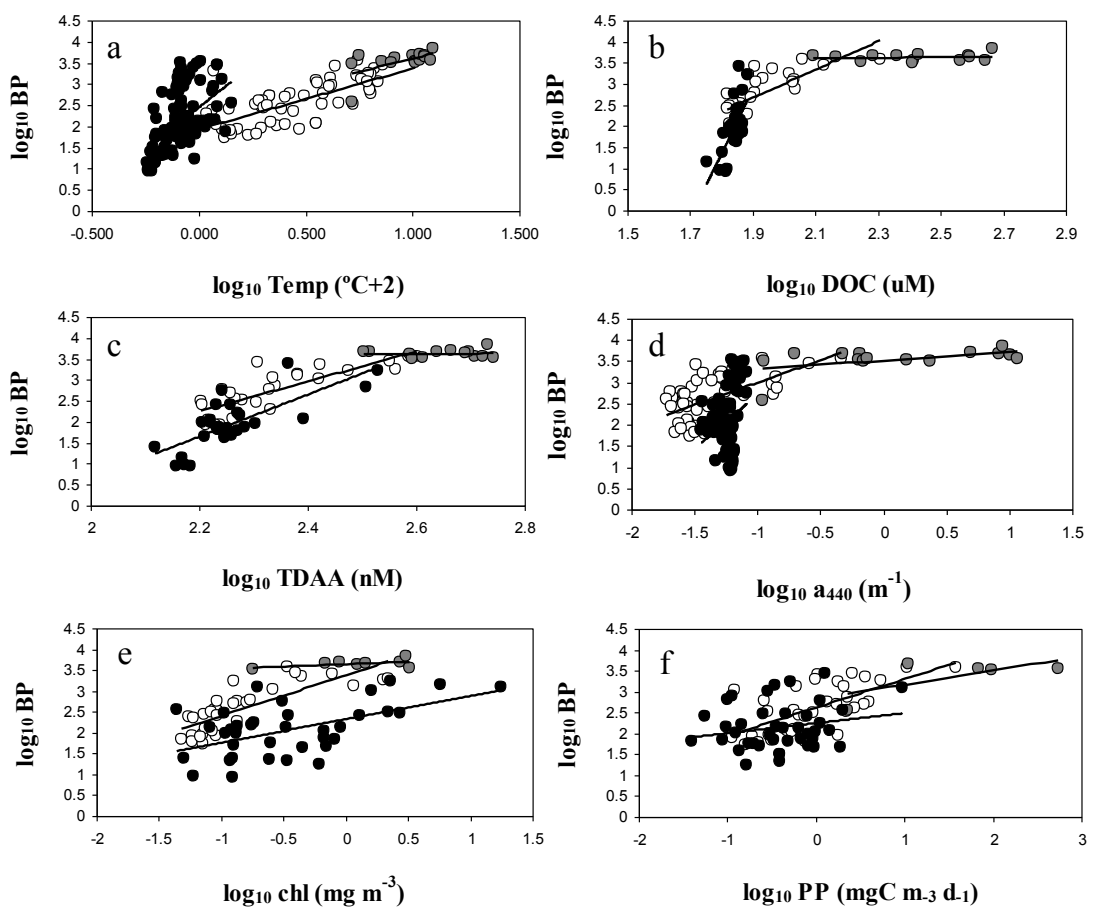

Fig. 5. Bivariate plots between different environmental variables and bacterial production (BP, $\mu \mathrm{g} \mathrm{C} \mathrm{m}^{-3} \mathrm{~d}^{-1}$ ), all $\log _{10}$ transformed. Grey circles: River samples. White circles: Upper Mixed Layer samples. Black circles: Below mixed layer samples. Results of the regression analyses are detailed in Table 3.

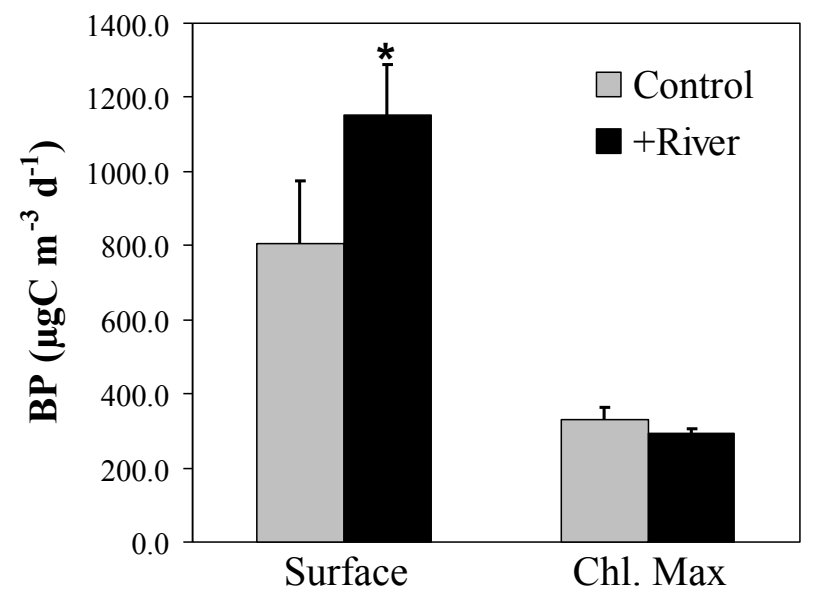

Fig. 6. Bacterial production ( $\left.\mu \mathrm{g} \mathrm{C} \mathrm{m} \mathrm{m}^{-3} \mathrm{~d}^{-1}\right)$ after $48 \mathrm{~h}$ incubations without (grey columns) and with (white columns) additions of $0.2 \mu \mathrm{m}$-filtered water from the Mackenzie River (10\%, vol: vol). Asterisk represent significant differences $(p<0.05)$.

attributed to the low temperatures and low labile substrate supply. However, the BP to PP ratios were relatively high and indeed higher than those reported by (Kirchman et al., 2009b) who discuss low BP to PP ratios in the Arctic. In our study, where oligotrophic conditions prevailed and low PP values were observed, bacteria incorporated a substantial amount $(81 \%)$ of fixed carbon.
The absence of a correlation between the proportion of HNA cells (\% HNA) and bacterial production or growth rates suggests that HNA cells were not the most active population in the area, contrary to observations reported during a seasonal study in the Beaufort Sea (Belzile et al., 2008). In the Southern Ocean, Ortega-Retuerta et al. (2008), in line with our finding, observed that LNA cells were more closely related to BP than HNA cells. In the present study, HNA and LNA subpopulations were likely governed by different forcings. \% HNA was higher in deep waters than in the upper mixed layer, and particularly in waters below $100 \mathrm{~m}$ (Table 1), which corresponded to Pacific Winter Water. It has been recently demonstrated in different oceanic regions that HNA and LNA populations corresponded to different bacterial species (Schattenhofer et al., 2011; Vila-Costa et al., 2012). This suggests that bacterial populations with different cytometric signatures likely corresponded to different communities with intrinsic metabolic properties, which were distributed along with water masses (Lovejoy et al., 2011).

\subsection{Bacterial respiration and net heterotrophy vs. autotrophy}

In contrast to BA and BP measurements, fewer data on bacterial respiration have been reported in the Arctic Ocean. The ones presented here are consistent with previous works (Table 5). Based on our respiration analyses, a mean $70.6 \%$ of community respiration was attributable to free-living 
Table 4. Bacterial production (BP, $\left.\mu \mathrm{g} \mathrm{C} \mathrm{m}{ }^{-3} \mathrm{~d}^{-1}\right)$, abundance $\left(\mathrm{BA}, \times 10^{5} \mathrm{cell} \mathrm{ml}^{-1}\right.$ ) growth rates $\left(\mathrm{GR}, \mathrm{d}^{-1}\right)$ and primary production $(\mathrm{PP}$, $\left.\mathrm{mg} \mathrm{C} \mathrm{m}{ }^{-3} \mathrm{~d}^{-1}\right)$ reported in previous studies in the Western Arctic Ocean and a study in the coastal Eastern Arctic Ocean. Studies performed in the same location as the present study are highlighted in bold.

\begin{tabular}{|c|c|c|c|c|c|c|c|}
\hline Area & Year & Month & $\mathrm{BP}(\min -\max )$ & $\mathrm{BA}(\min -\max )$ & GR (min-max) & $\mathrm{PP}$ & Reference \\
\hline Mackenzie Shelf & 2009 & Aug & $897.1(8.8-7078)$ & $4.3(0.8-16.2)$ & $0.08(0.01-0.54)$ & $4.32(0.03-545)$ & This study \\
\hline Bering and Chukchi Seas & 1992 & Aug-Sep & $150-17000$ & & $0.06-0.84$ & & (Steward et al., 1996) \\
\hline Chukchi Sea & 1993 & Aug & $\begin{array}{l}\text { Shelf: } 115.2 \\
\text { Slope: } 232.8 \\
\text { Basin: } 146.4\end{array}$ & $2-5$ & & $\begin{array}{l}\text { Shelf: } 336 \\
\text { Slope: } 394 \\
\text { Basin: } 74\end{array}$ & (Cota et al., 1996) \\
\hline Resolute Bay, Canada & 1999 & Mar/Dec & & $0.6-3.3$ & $<0.2-1$ & & (Anderson and Rivkin, 2001) \\
\hline Chukchi and Beaufort Seas & 2000 & Aug & & $\begin{array}{l}\text { Chukchi : } 5.7(0.8-8.7) \\
\text { Beaufort: } 1.8(1.8-1.9)\end{array}$ & & & (Hodges et al., 2005) \\
\hline Chukchi and Beaufort Seas & $\begin{array}{l}2002 \\
2004\end{array}$ & $\begin{array}{l}\text { Jul-Aug } \\
\text { “ }\end{array}$ & & $0.3-13$ & $0.07(0.02-0.14)$ & $\begin{array}{l}458 \\
1581\end{array}$ & (Kirchman et al., 2009a) \\
\hline Mackenzie shelf and Beaufort Sea & 2002 & Sep-Oct & $48(12-112)$ & $\begin{array}{l}\text { River: } 13 \\
\text { Coast: } 4.3 \\
\text { Offshore: } 2.3\end{array}$ & & & (Garneau et al., 2006) \\
\hline Franklin Bay (Beaufort Sea) & 2004 & Feb-Mar & & $1.2-3$ & & & (Wells and Deming, 2006) \\
\hline Franklin Bay (Beaufort Sea) & 2003-2004 & Nov/Aug & $6.6-163$ & $0.873-10.7$ & & & (Garneau et al., 2008) \\
\hline Mackenzie River and Beaufort Sea & 2004 & Jun-Jul & $820(220-2250)$ & $8.8(5.7-13.6)$ & $0.07(0.02-0.19)$ & & (Garneau et al., 2009) \\
\hline Mackenzie River and Beaufort Sea & 2004 & Jul-Aug & 4272-9360 & & & $12-466$ & $\begin{array}{l}\text { (Retamal et al., 2008; } \\
\text { Vallières et al., 2008) }\end{array}$ \\
\hline $\begin{array}{l}\text { Amundsen Gulf } \\
\text { Other Arctic Coastal system }\end{array}$ & $2007-2008$ & Nov-Jul & $146(0-2680)$ & $2.73(0.72-12.3)$ & & & (Nguyen et al., 2012) \\
\hline $\mathrm{Ob}$ and Yenisei Rivers and Kara Sea & 2001 & Aug-Sep & $\begin{array}{l}\text { River: } 13500 \\
\text { Estuary: } 5800 \\
\text { Kara Sea: } 2400\end{array}$ & $\begin{array}{l}15.1 \\
19.3 \\
<5\end{array}$ & & $\begin{array}{l}155 \\
127 \\
57\end{array}$ & (Meon and Amon, 2004) \\
\hline
\end{tabular}

Table 5. Respiration measurements (total or with fractionation) and bacterial growth efficiencies (BGE) reported from the Arctic Ocean.

\begin{tabular}{|c|c|c|c|c|c|c|}
\hline Area & Year & Month or season & Fraction used & $\begin{array}{r}\text { Respiration } \\
\left(\mathrm{mg} \mathrm{O}_{2} \mathrm{~m}^{-3} \mathrm{~d}^{-1}\right)\end{array}$ & $\operatorname{BGE}(\%)$ & Reference \\
\hline \multirow[t]{2}{*}{ Mackenzie shelf and Beaufort Sea } & 2009 & Aug & whole & $20.1(5.5-45.5)$ & $7.7(0.4-19.8)$ & This study \\
\hline & & & $<1$ & $20.1(4.1-33.8)$ & $5.5(0.2-25.5)$ & \\
\hline \multirow[t]{2}{*}{ Chukchi and Beaufort Seas } & 2002 and 2004 & Jul-Aug & whole & $53.2(0-239)$ & & (Kirchman et al., 2009a) \\
\hline & & & $<0.8$ & $21(0.3-94.8)$ & $6.9(0.6-31.6)$ & \\
\hline Amundsen Gulf (Beaufort Sea) & $2007-2008$ & Nov-Jul & whole* & $6.74(1.84-18.1)$ & $4.6(0.2-18.1)$ & (Nguyen et al., 2012) \\
\hline $\mathrm{Ob}$ and Yenisei Rivers and Kara Sea & 2001 & Aug-Sep & $<0.8$ & $12.5(4.1-26.3)$ & $19(10-39)$ & (Meon and Amon, 2004) \\
\hline \multirow[t]{3}{*}{ Central Arctic } & 1997-1998 & Fall-winter & whole & 7.142 & & (Sherr and Sherr, 2003) \\
\hline & & Winter & “ & 3.196 & & \\
\hline & & Spring-summer & “ & 10.166 & & \\
\hline Greenland Current & 2007 & Jul & whole & $25.2(2.9-44.9)$ & & (Regaudie-de-Gioux and Duarte, 2011) \\
\hline Fram Strait & 2007 & “ & “ & $74.8(12.1-350)$ & & \\
\hline Fram Strait & 2008 & Jul-Aug & $<10$ & $7.25(2.6-16.8)$ & $6.3(2-9)$ & (Kritzberg et al., 2010) \\
\hline
\end{tabular}

na: not available

* converted from TCR after Robinson et al. (2005)

bacteria (e.g., bacteria passing through $1 \mu \mathrm{m}$ filters), higher than reported by Kirchman et al. (2009a) for Arctic waters, but in the range of other studies that calculated TCR and BR using size fractionation (mean $=56 \%$ according to Robinson and Williams, 2005). Although size fractionation has been generally used to measure BR, this procedure may lead to biases due to the minimisation of grazing or to the exclusion of bacteria attached to particles from the measured rate. In fact, a significant reduction of grazers by filtration (Pomeroy et al., 1994) could account for the higher respiration rates measured in fractionated samples than in whole samples in one of our experiments (Table 2). In our case, size fractionated BP determinations ( $3 \mu \mathrm{m}$ by gravity) showed that $36 \%$ on average of total BP was due to BP attached to particles ( $n=121$, data not shown), suggesting that also a significant fraction of BR is due to particle-attached bacteria. Thus, we decided to use TCR values instead of BR to calculate values of BGE and BCD. However, if we made the same analyses using size fractionated BR data, the resulting numbers would lead to minor changes in BGE $(5.5 \%$ instead of $7.7 \%)$ and BCD (20.8 instead of $21.5 \mathrm{mg} \mathrm{C} \mathrm{m}^{-3} \mathrm{~d}^{-1}$ ), not changing the general net heterotrophy vs. autotrophy patterns. Similarly, the same trends of autotrophy vs. heterotrophy are observed when using BR calculated as a fraction TCR using the model of Robinson (2008), even though BR values calculated using this model are on average $46 \%$ smaller than the measured BR values.

BGE in our work (mean $7.7 \%$ ) showed similar values to those previously reported by Kirchman et al. (2009a) and Ngyuen et al. (2012) in the Western Arctic (6.9\% and $4.6 \%$ in Chukchi and Beaufort Seas), although lower than the $19 \%$ reported in another coastal Arctic Site, the Kara Sea (Meon 
and Amon, 2004) (Table 5). However, different analytical methods would lead to higher BGE values. For instance, these authors used a higher leucine to $\mathrm{C}$ conversion factor ( $2.3 \mathrm{~kg} \mathrm{C} \mathrm{mol}^{-1}$ vs. the $1.5 \mathrm{~kg} \mathrm{C} \mathrm{mol}^{-1}$ used in our study) and BR was determined only in the fraction of less than $0.8 \mu \mathrm{m}$ instead of whole seawater. Substrate quality has been postulated as controlling factors of BGE and is in accordance with our results, as BGE was higher in coastal stations where TDAA concentrations were higher.

Our comparisons between BCD and PP demonstrated that during our study the coastal Beaufort Sea was net heterotrophic, while the stations located in the Mackenzie River mouth where net autotrophic (Fig. 4). This last observation suggests that the excess carbon fixed by PP in the river plume was likely transported downstream and used in the coastal Beaufort Sea, where the highest BCD to PP ratios are observed (Fig.4). We cannot exclude that dissolved primary production, not measured in this study, contributed partially to the BCD. Although there are no published data on phytoplankton extracellular carbon release in the Beaufort Sea margin, previous studies in the Arctic have reported values from less than $3 \%$ (Müller-Niklas and Herndl, 1996) up to $65 \%$ (Gosselin et al., 1997). Even using this upper value, BCD: total phytoplankton production ratio would remain higher than 1 (3.7 on average).

Alternative non-exclusive organic matter sources for an excess in carbon demand are terrestrial carbon transported with the river or carbon fixed during the more productive spring season. A decoupling between production and respiration processes was already pointed out by Cottrell et al. (2006) in the Chukchi and Beaufort Seas. A previous study performed at the end of July in the Mackenzie River plume (Vallières et al., 2008) found opposite patterns to those reported in this study: while the Mackenzie River area was net heterotrophic, the coastal Beaufort Sea was autotrophic. While BP values were of the same magnitude in both studies (Table 5), the main difference between both, when comparing stations with the same location, was in terms of PP (Table 4), where our values were 1 to 2 orders of magnitude lower. In fact, in our study, bacterial carbon demand ranged within the same order of magnitude, while PP varied over 4 orders of magnitude, from 0.03 to $544 \mathrm{mg} \mathrm{C} \mathrm{m}^{-1} \mathrm{~d}^{-1}$. Thus, the variability in autotrophic vs. heterotrophic patterns in the study region are mostly driven by differences in PP. The marked differences in PP between the works of Vallières et al. (2008) and ours may be explained by interannual variability, high in the Arctic Ocean (Kirchman et al., 2009a), but also to seasonal variability. In our study, performed later in summer (1-27 August vs. July), PP is likely lower due to nutrient depletion and lower light availability. Also, water discharge and the associated organic matter and inorganic nutrients supply by the Mackenzie River (and other Arctic rivers) is lower in August than in July (Serreze et al., 2002; Spencer et al., 2008).

\subsection{Controlling factors of bacterial production in the coastal Beaufort Sea}

It has been hypothesized that labile organic matter rather than temperature controls bacterial activity in the Arctic (Kirchman et al., 2009a, b). Based on our multiple regression analyses we cannot rule out a driving effect of BP by temperature particularly in the upper layer. If we calculated the $Q_{10}$ in the river stations and the upper mixed layer using the slope of the regression between temperature and log-normalised growth rates (Kirchman et al., 2009b), we would obtain a value greater than 100 (data not shown), suggesting a high sensitivity of bacterial activity to temperature. However, these high $Q_{10}$ values would look unrealistic given that previous $Q_{10}$ estimated from incubations in the Western Arctic were always lower than 10 (Kirchman et al., 2005). We hypothesize that temperature and labile organic substrate would interact to drive BP, as postulated by Pomeroy and Wiebe (2001).

Regression analyses also showed that BP in the study area are primarily controlled by organic matter supply, and in particular by the availability of labile organic compounds, as the regressions were closer with TDAA (proxy of labile organic matter) than with the total DOC pool, particularly evident in the upper mixed layer (Table 3 ) and confirmed by partial regression coefficients calculation. This suggests that in surface waters a relatively low proportion of organic carbon in the area is labile. In fact, the concentrations of amino acids and the fraction of DOC as amino acids was low compared to other areas in the Western Arctic (Davis and Benner, 2005; Shen et al, 2012). This is particularly important if a high proportion of organic matter comes from the river, where the amino acid yields were substantially lower $(0.58 \%)$ than in the Beaufort sea $(0.82 \%$ and $0.88 \%$ above and below the upper mixed layer, respectively). We note the weaker relationship with PP and Chl $a$ than with TDAA (Table 3), which again supported the decoupling between carbon fixation and consumption processes. This is in line with the general scenario of heterotrophy, where bacteria are fueled by alternative organic matter sources such as organic carbon fixed upstream in the Mackenzie River.

The enrichment experiments pointed to a stimulation of BP by organic matter coming from the Mackenzie River only in surface waters. Nutrient enrichment experiments performed during the same cruise (Ortega-Retuerta et al., 2012) showed BP limitation by nitrogen in surface waters of the study area, while carbon limitation or no substrate limitations were observed in chlorophyll maxima waters. Therefore, the stimulation of BP by river water addition at the surface was probably due to an increase in nitrogen, with the subsequent alleviation of this limitation, rather to an increase in dissolved organic carbon. This can be calculated by the concentrations of added $\mathrm{C}$ and $\mathrm{N}$ versus the ambient concentrations. While riverine DOC added $(228 \mu \mathrm{M})$ involved substantial $(\sim 20 \%)$ DOC increases over ambient DOC in both surface $(65 \mu \mathrm{M})$ and Chl Max $(73 \mu \mathrm{M})$ concentrations, 
river additions led to $10 \%$ increases of total dissolved nitrate $(0.13 \mu \mathrm{M})$, over ambient concentrations $(0.01 \mu \mathrm{M})$ in the surface, explaining the observed stimulation in BP. Conversely, at the Chl $a$ max, the addition yielded a decrease in nitrate of $8 \%$ over ambient concentrations $(0.62 \mu \mathrm{M})$, resulting in a lack of stimulation, or even a slight inhibition of BP (Fig. 6). However, it is worth noting the high $\mathrm{C}$ to $\mathrm{N}$ ratios and low amino acid yield of Mackenzie River water, that would lead, after microbial communities uptake and consume all $\mathrm{N}$ provided by the river, to an accumulation of refractory organic carbon in the system that would be prone to export to from the shelf to the central Arctic basin (Davis and Benner, 2005).

\section{Conclusions}

We can summarise our major findings in the following points. Firstly, based on in situ observations, highest BP and BA values were, unlike chlorophyll, generally situated in surface waters and the coastal area, which were mostly influenced by the Mackenzie River discharge. Secondly, we reported a situation of net heterotrophy in the coastal Beaufort Sea. Hence, bacteria in the area can be consuming organic carbon coming from sources other than photosynthesis, particularly carbon that is fixed upstream in the river, where we found the only autotrophic stations. An increase in heterotrophy in the Arctic Ocean, already observed fifteen years ago (Cota et al., 1996) is predictable under a scenario of higher terrestrial inputs due to larger river discharge. Therefore, a further accumulation of organic carbon in the system, owing to its low lability, is likely to occur. Thirdly, regression analyses highlighted a primary control of bacterial production by temperature and labile organic matter supply, represented by TDAA. Finally, the experiment results suggested that Mackenzie River waters could partially alleviate substrate limitations of bacterioplankton in surface waters of the Beaufort Sea, but an accumulation and presumably export of Riverine organic matter to other Arctic areas is to occur as a consequence of further limitation by nitrogen.

Acknowledgements. We thank the captain and crew of the Canadian icebreaker Amundsen for their support in the field. This work was supported by the French National Research Agency, under the grant no. ANR-BLAN08-1_310980 to the MALINA project, the LEFE-CYBER and CNES TOSCA programmes, and the European Space Agency. W.H.J was supported by a University of West Florida faculty scholarly and creative activity award. R. B. was supported by the US NSF (grant no 0713915). We also thank two anonymous referees for helpful comments in a previous version of this MS.

Edited by: W. Li

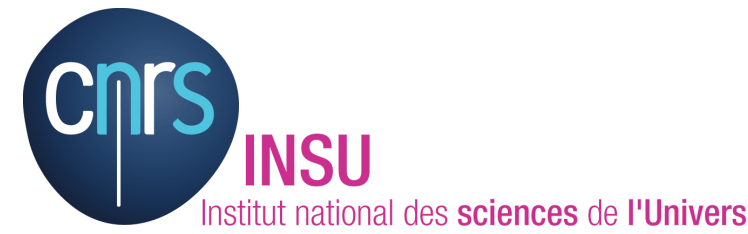

The publication of this article is financed by CNRS-INSU.

\section{References}

Anderson, M. R. and Rivkin, R. B.: Seasonal patterns in grazing mortality of bacterioplankton in polar oceans: a bipolar comparison, Aquat. Microb. Ecol., 25, 195-206, 2001.

Azam, F., Fenchel, T., Field, J. G., Gray, J. S., Meyerreil, L. A., and Thingstad, F.: The ecological role of water column microbes in the sea, Mar. Ecol.-Prog. Ser., 10, 257-263, 1983.

Bates, N. R., Cai, W. J., and Mathis, J. T.: The Ocean Carbon Cycle in the Western Arctic Ocean. Distributions and air-sea fluxes of carbon dioxide, Oceanography, 24, 186-201, 2011.

Belzile, C., Brugel, S., Nozais, C., Gratton, Y., and Demers, S.: Variations of the abundance and nucleic acid content of heterotrophic bacteria in Beaufort Shelf waters during winter and spring, J. Marine Syst., 74, 946-956, 2008.

Carrignan, R., Blais, A.-M., and Vis, C.: Measurement of primary production and community respiration in oligotrophic lakes using Winkler method, Can. J. Fish. Aquat. Sci., 55, 1078-1084 1998.

Comeau, A. M., Li, W. K. W., Tremblay, J.-Ã. R., Carmack, E. C., and Lovejoy, C.: Arctic Ocean Microbial Community Structure before and after the 2007 Record Sea Ice Minimum, PLoS ONE, 6, e27492, doi:10.1371/journal.pone.0027492 2011.

Cota, G. F., Pomeroy, L. R., Harrison, W. G., Jones, E. P., Peters, F., Sheldon, W. M., and Weingartner, T. R.: Nutrients, primary production and microbial heterotrophy in the southeastern Chukchi Sea: Arctic summer nutrient depletion and heterotrophy, Mar. Ecol.-Prog. Ser., 135, 247-258, 1996.

Cottrell, M. T. and Kirchman, D. L.: Contribution of major bacterial groups to bacterial biomass production (thymidine and leucine incorporation) in the Delaware Estuary, Limnol. Oceanogr., 48, 168-178, 2003.

Cottrell, M. T., Malmstrom, R. R., Hill, V., Parker, A. E., and Kirchman, D. L.: The metabolic balance between autotrophy and heterotrophy in the western Arctic Ocean, Deep-Sea Res. Pt. I, 53, 1831-1844, doi:10.1016/j.dsr.2006.08.010, 2006.

Davis, J. and Benner, R.: Seasonal trends in the abundance, composition and bioavailability of particulate and dissolved organic matter in the Chukchi/Beaufort Seas and western Canada Basin, Deep-Sea Res. Pt. II, 52, 3396-3410, 2005.

del Giorgio, P. A. and Cole, J. J.: Bacterial Growth Efficiency in Natural Aquatic Systems, Annu. Rev. Ecol. Syst., 29, 503-541, 1998.

Garneau, M. E., Vincent, W. F., Alonso-Saez, L., Gratton, Y., and Lovejoy, C.: Prokaryotic community structure and heterotrophic production in a river-influenced coastal arctic ecosystem, Aquat. Microb. Ecol., 42, 27-40, 2006.

Garneau, M. E., Roy, S., Lovejoy, C., Gratton, Y., and Vincent, W. F.: Seasonal dynamics of bacterial biomass and production in a coastal arctic ecosystem: Franklin Bay, west- 
ern Canadian Arctic, J. Geophys. Res.-Oceans, 113, C07s91, doi:10.1029/2007jc004281, 2008.

Garneau, M. E., Vincent, W. F., Terrado, R., and Lovejoy, C.: Importance of particle-associated bacterial heterotrophy in a coastal Arctic ecosystem, J. Marine Syst., 75, 185-197, doi:10.1016/j.jmarsys.2008.09.002, 2009.

Gasol, J. M., Zweifel, U. L., Peters, F., Fuhrman, J. A., and Hagstrom, A.: Significance of size and nucleic acid content heterogeneity as measured by flow cytometry in natural planktonic bacteria, Appl. Environ. Microb., 65, 4475-4483, 1999.

Gosselin, M., Levasseur, M., Wheeler, P. A., Horner, R., and Booth, B. C.: New measurements of phytoplankton and ice algal production in the Arctic Ocean, Deep-Sea Res. Pt. II, 44, 1623-1644, 1997.

Hodges, L. R., Bano, N., Hollibaugh, J. T., and Yager, P. L.: Illustrating the importance of particulate organic matter to pelagic microbial abundance and community structure - an Arctic case study, Aquat. Microb. Ecol., 40, 217-227, 2005.

Hollibaugh, J. T., Lovejoy, C., and Murray, A. E.: Microbiology in polar oceans, Oceanography, 20, 140-145, 2007.

Kirchman, D. L.: Leucine incorporation as a measure of biomass production by heterotrophic bacteria, in: Handbook of methods in aquatic microbial ecology, edited by: Kemp, P. F., Sherr, B. F., Sherr, E. B., and Cole, J. J., Lewis Publishers, Boca Raton, 509-512, 1993.

Kirchman, D. L., Malmstrom, R. R., and Cottrell, M. T.: Control of bacterial growth by temperature and organic matter in the Western Arctic, Deep-Sea Res. Pt. II, 52, 3386-3395, 2005.

Kirchman, D. L., Hill, V., Cottrell, M. T., Gradinger, R., Malmstrom, R. R., and Parker, A.: Standing stocks, production, and respiration of phytoplankton and heterotrophic bacteria in the western Arctic Ocean, Deep-Sea Res. Pt. II, 56, 1237-1248, doi:10.1016/j.dsr2.2008.10.018, 2009a.

Kirchman, D. L., Moran, X. A. G., and Ducklow, H.: Microbial growth in the polar oceans - role of temperature and potential impact of climate change, Nat. Rev. Microbiol., 7, 451-459, doi:10.1038/nrmicro2115, 2009b.

Kritzberg, E., Duarte, C., and Wassmann, P.: Changes in Arctic marine bacterial carbon metabolism in response to increasing temperature, Polar Biol., 33, 1673-1682, 2010.

Lalande, C., Forest, A., Barber, D. G., Gratton, Y., and Fortier, L.: Variability in the annual cycle of vertical particulate organic carbon export on Arctic shelves: Contrasting the Laptev Sea, Northern Baffin Bay and the Beaufort Sea, Cont. Shelf Res., 29, $2157-$ 2165, doi:10.1016/j.csr.2009.08.009, 2009.

Lee, S. and Fuhrman, J. A.: Relationships between biovolume and biomass of naturally derived marine bacterioplankton, Appl. Environ. Microb., 53, 1298-1303, 1987.

Lovejoy, C., Galand, P. E., and Kirchman, D. L.: Picoplankton diversity in the Arctic Ocean and surrounding Seas, Marine Biodiversity, 41, 5-12, 2011.

Matsuoka, A., Bricaud, A., Benner, R., Para, J., Sempéré, R., Prieur, L., Bélanger, S., and Babin, M.: Tracing the transport of colored dissolved organic matter in water masses of the Southern Beaufort Sea: relationship with hydrographic characteristics, Biogeosciences, 9, 925-940, doi:10.5194/bg-9-925-2012, 2012.

McLaughlin, F., Carmack, E., Proshutinsky, A., Krishfield, R. A., Guay, C., Yamamoto-Kawai, M., Jackson, J. M., and Williams, B.: The rapid response of the Canada Basin to climate forc- ing: From bellwether to alarm bells, Oceanography, 24, 146-159, 2011.

Meon, B. and Amon, R. M. W.: Heterotrophic bacterial activity and fluxes of dissolved free amino acids and glucose in the Arctic rivers $\mathrm{Ob}$, Yenisei and the adjacent Kara Sea, Aquat. Microb. Ecol., 37, 121-135, 2004.

Müller-Niklas, G. and Herndl, G. J.: Dynamics of bacterioplankton during a phytoplankton bloom in the high Arctic waters of the Franz-Joseph Land archipelago, Aquat. Microb. Ecol., 11, 111118, doi:10.3354/ame011111, 1996.

Nguyen, D., Maranger, R., Tremblay, J.-É., and Gosselin, M.: Respiration and bacterial carbon dynamics in the Amundsen Gulf, western Canadian Arctic, J. Geophys. Res., 117, C00G16, doi:10.1029/2011JC007343, 2012.

Ortega-Retuerta, E., Reche, I., Pulido-Villena, E., Agusti, S., and Duarte, C. M.: Exploring the relationship between active bacterioplankton and phytoplankton in the Southern Ocean, Aquat. Microb. Ecol., 52, 99-106, 2008.

Ortega-Retuerta, E., Jeffrey, W., Ghiglione, J., and Joux, F.: Evidence of heterotrophic prokaryotic activity limitation by nitrogen in the Western Arctic Ocean during summer, Polar Biol., 35, 785-794, 2012.

Parsons, T., Mayta, Y., and Lalli, C.: A manual of chemical and biological methods for seawater analysis, edited by: Press, P., Oxford, 1984.

Perovich, D. K.: The changing Arctic sea ice cover, Oceanography, 24, 162-173, 2011.

Peterson, B. J., Holmes, R. M., McClelland, J. W., Vorosmarty, C. J., Lammers, R. B., Shiklomanov, A. I., Shiklomanov, I. A., and Rahmstorf, S.: Increasing river discharge to the Arctic Ocean, Science, 298, 2171-2173, 2002.

Pomeroy, L. R. and Wiebe, W. J.: Temperature and substrates as interactive limiting factors for marine heterotrophic bacteria, Aquat. Microb. Ecol., 23, 187-204, doi:10.3354/ame023187, 2001.

Pomeroy, L. R., Sheldon, J. E., and Sheldon, W. M.: Changes in Bacterial Numbers and Leucine Assimilation during Estimations of Microbial Respiratory Rates in Seawater by the Precision Winkler Method, Appl. Environ. Microb., 60, 328-332, 1994.

Raimbault, P. and Garcia, N.: Evidence for efficient regenerated production and dinitrogen fixation in nitrogen-deficient waters of the South Pacific Ocean: impact on new and export production estimates, Biogeosciences, 5, 323-338, doi:10.5194/bg-5323-2008, 2008.

Regaudie-de-Gioux, A. and Duarte, C. M.: Plankton metabolism in the Greenland Sea during the polar summer of 2007, Polar Biol. 33, 1651-1660, doi:10.1007/s00300-010-0792-1, 2011.

Retamal, L., Bonilla, S., and Vincent, W. F.: Optical gradients and phytoplankton production in the Mackenzie River and the coastal Beaufort Sea, Polar Biol., 31, 363-379, 2008.

Robinson, C.: Heterotrophic bacterial respiration, in: *Microbial Ecology of the Oceans, 2nd Edition, edited by: Kirchman, D. L., John Wiley \& Sons, Inc., 299-334, 2008.

Robinson, C. and Williams, P.: Respiration and its measurements in surface marine waters, in: Respiration in Aquatic Ecosystems, edited by: Williams, P. and del Giorgio, P., Oxford University Press, New York, NY, 2005.

Schattenhofer, M., Wulf, J., Kostadinov, I., Glöckner, F. O., Zubkov, M. V., and Fuchs, B. M.: Phylogenetic characterisation of pi- 
coplanktonic populations with high and low nucleic acid content in the North Atlantic Ocean, Syst. Appl. Microbiol., 34, 470475, 2011.

Serreze, M. C., Bromwich, D. H., Clark, M. P., Etringer, A. J., Zhang, T., and Lammers, R.: Large-scale hydro-climatology of the terrestrial Arctic drainage system, J. Geophys. Res., 107, 8160, doi:10.1029/2001JD000919, 2002.

Shen, Y., Fichot, C. G., and Benner, R.: Dissolved organic matter composition and bioavailability reflect ecosystem productivity in the Western Arctic Ocean, Biogeosciences Discuss., 9, 95719601, doi:10.5194/bgd-9-9571-2012, 2012.

Sherr, B. F. and Sherr, E. B.: Community respiration/production and bacterial activity in the upper water column of the central Arctic Ocean, Deep-Sea Res. Pt. I, 50, 529-542, doi:10.1016/s09670637(03)00030-x, 2003.

Smith, D. C. and Azam, F.: A simple, economical method for measuring bacterial protein synthesis rates in seawater using $3 \mathrm{H}-$ leucine, Mar. Microb. Food Webs, 6, 107-114, 1992.

Spencer, R. G. M., Aiken, G. R., Wickland, K. P., Striegl, R. G., and Hernes, P. J.: Seasonal and spatial variability in dissolved organic matter quantity and composition from the Yukon River basin, Alaska, Global Biogeochem. Cy., 22, GB4002, doi:10.1029/2008GB003231, 2008.
Steward, G. F., Smith, D. C., and Azam, F.: Abundance and production of bacteria and viruses in the Bering and Chukchi Seas, Mar. Ecol.-Prog. Ser., 131, 287-300, 1996.

Vallières, C., Retamal, L., Ramlal, P., Osburn, C. L., and Vincent, W. F.: Bacterial production and microbial food web structure in a large arctic river and the coastal Arctic Ocean, J. Marine Syst., 74, 756-773, doi:10.1016/j.jmarsys.2007.12.002, 2008.

Vila-Costa, M., Gasol, J. M., Sharma, S., and Moran, M. A.: Community analysis of high- and low-nucleic acid-containing bacteria in NW Mediterranean coastal waters using $16^{\circ} \mathrm{S}$ rDNA pyrosequencing, Environ. Microbiol., 14, 1390-1402, doi:10.1111/j.1462-2920.2012.02720.x, 2012.

Wells, L. E. and Deming, J. W.: Significance of bacterivory and viral lysis in bottom waters of Franklin Bay, Canadian Arctic, during winter, Aquat. Microb. Ecol., 43, 209-221, 2006.

Wheeler, P. A., Gosselin, M., Sherr, E., Thibault, D., Kirchman, D. L., Benner, R., and Whitledge, T. E.: Active cycling of organic carbon in the central Arctic Ocean, Nature, 380, 697-699, 1996. 